\title{
Paratransit Business Strategies: A Bird's-Eye View of Matatus in Nairobi
}

\author{
Dorothy McCormick, Winnie Mitullah, Preston Chitere \\ University of Nairobi \\ Risper Orero, Kenya Methodist University \\ Marilyn Ommeh, University of Nairobi
}

\begin{abstract}
Nairobi's paratransit vehicles-called matatus-provide most of the City's public transport. They are operated as private for-profit businesses with varying levels of investment, labor, and strategic thinking. The vehicles are subject to regulation but have little regard for laws, regulations, or the comfort of the traveling public. Interviews of informed observers-the "bird's-eye view"-underscored the business character of matatu firms and revealed considerable variation in business structure, modes of operation, levels of organization, and attitudes towards regulation, and they highlighted ways that government and industry institutions affect matatu organization and operations. This study identified eight elements of matatu business strategy and a continuum of business organization; it also noted an emerging trend towards higher levels of organization through franchising, networking, and ownership of multiple vehicles. The paper suggests that further development of varied organizational forms could hold the key to a more user-friendly public transport system for Nairobi.
\end{abstract}




\section{Introduction}

Paratransit is the main form of public transport in many African cities. The vehicles go by various names, such as "matatus" in Nairobi, "dala dala" in Dar es Salaam, and "minibus taxis" in Cape Town. In developed countries, paratransit is, as its name suggests, a mode of transport that operates parallel to an organized, usually large-scale government-run or government-subsidized transport system. In many African countries, for a variety of reasons, the parallel system has become the main public transport system available. It is, therefore, crucial to understand how it operates.

The matatu mode of transport provides most of Nairobi's public transport services (Aligula et al. 2005). The matatus are owned by individuals and private companies, and so form part of Nairobi's private sector. An important characteristic of Nairobi's paratransit is its almost total lack of adherence to traffic rules, prescribed routes, and regulatory requirements. The resulting chaotic behavior has long been referred to as "matatu madness" (see East African Standard 1998; Daily Nation 1999). Yet, despite this apparent similarity in behavior, matatu businesses differ from each other in important ways. Some of these differences are readily observable. Equipment ranges from shabby vans and buses that have long been battered by encounters with other vehicles to brightly-painted minibuses equipped with hostesses and built-in DVD players. Many have music systems, but the volume and the type of music played vary from one to another. Youth form the bulk of the passengers for some, while others carry mainly older commuters and shoppers. Differences in the propensity to break speed limits, vary fares, deviate from approved routes, harass passengers, and/or obstruct traffic are also easy to see.

Less observable are differences in owner characteristics, age and history of the business, forms of internal organization, linkages with other actors, amount and type of financing, type of vehicle ownership, route assignment, and number and types of external linkages that businesses form with other actors within and outside their own sector of operation. Theories of institutions and firm strategic behavior suggest that these and other differences may not simply be "matatu madness" but are, in fact, part of the market and business development strategies of matatu firms.

The project's overall research question is, therefore: To what extent do firms with different strategies respond differently to actual or proposed regulations, and what are the implications of these differences for the government's ability to implement change? The questions driving this paper were, however, somewhat more limited because the paper seeks to provide a basic understanding of the main elements 
of paratransit business strategies in Nairobi. The research covers public transport operating in Nairobi City. Matatus are its subjects, and its sources of data are informed observers of the matatu sector. The paper aims to provide a basic understanding of the institutional context and the main elements of paratransit business strategies in Nairobi as preparation for a more detailed firm-level study.

Research for this paper took the form of a scoping study that aimed at identifying the main features of strategy development and implementation among Nairobi's paratransit operators as seen by knowledgeable observers. It took, in other words, a "bird's-eye view" of the matatu industry. Primary data were gathered through indepth interviews of 18 purposively-selected key informants and feedback during a stakeholders workshop. Data analysis was qualitative and thematic.

The paper is organized into six parts. The following section reviews relevant literature. Part 3 puts the study into a theoretical context and briefly examines empirical findings on urban transport strategies. Part 4 outlines the research methodology. Part 5 presents the findings, and Part 6 summarizes and draws conclusions from the findings.

\section{Urban Paratransit}

Paratransit vehicles are part of Kenya's urban public transport system. Public transportation is a service provided by public or private entities and is available to all persons who pay the prescribed fare (Vuchic n.d.). Urban public transport has been defined as a system that provides for the movement of people and goods within an urban area and also links the city to its environs (Aligula et al 2005). Paratransit operators in the global North and South spring up to fulfill unsatisfied demand for public transport as result of urban growth. However, whereas in the global North they form a tiny minority (Cervero 1997; Lee 1990; Örn 2005), in the global South, in most cases, the share of demand served by such paratransit operators is often 50 percent and sometimes accounts for all public transport services in the urban areas (Cervero 2000; Boudreaux 2006; Chitere and Kibua 2004). Paratransit vehicles vary from human-powered pedicabs to mid-sized motorised buses (Cervero 2000; Illes 2005).

Most paratransit operations in developing countries are supplied by the private sector rather than the public sector (Sclar et al. 2007). Many observers attribute the shift to private-sector transport to inefficiencies in the major public transport companies (Khayesi 2002; Cervero and Golub 2007; Sclar et al. 2007; Schalekamp et al., 2008). Some point out that in much of Africa and in smaller Asian cities where 
municipal budgets are stretched thin and technical capacities for planning, administration, and regulation are insufficient, almost by default, informal transport offers the only dependable services available (Cervero and Golub 2007). An earlier study by Golub (2005) also confirmed that, in many cities, regular public transportation systems do not meet all of the demands of the marketplace, and small-scale operators, legally or illegally, enter the market to fill these gaps. Such small operators typically have little transportation business expertise (Chitere 2006; Finn et al. 2011). Mũnoz and Gschwender (2008) argue that atomized ownership leads to increased traffic rule violations and a deterioration of services.

Where large numbers of private-sector operators provide public transport, regulating and controlling such individually-owned small vehicles is a serious challenge (Sohail et al. 2004). This is especially so because the vehicles represent a multiplicity of small businesses, each of which is trying to make a profit. This has led authorities in some African cities to focus on the question of whether an effort should be made to "formalize" or regulate paratransit operations and to try to identify the obstacles to such formalization (Kumar and Barrett 2008 (Wilkinson 2008; Wilkinson et al. 2011). A range of options for managing competition have been advanced, including public monopolies, management contracting, public-private partnerships, concessioning, and quality licensing (Sohail et al. 2004; Wilkinson 2008; Kumar and Barrett 2008; Chitere 2009). Choosing among these options requires a good understanding of the variety and, especially, the private-sector nature of paratransit operators. Research in various countries has shown that urban bus services respond to changing contexts in many different ways. In other words, there is no unique solution to the problems facing paratransit in developing countries (Finn and Mulley 2011).

\section{Business Strategies of Urban Transport Firms}

\section{Business Strategies}

Understanding a business strategy requires a clear notion of what a business is. This is particularly important in the case of urban public transport, because the experience of industrialized countries is that transport operators are usually public, rather than private, entities. A business is simply a private firm that aims to make a profit.' There is no universal definition of business strategy (Kelly and Kouzmin 2009). We adopt a basic definition that can fit large and small firms: A strategy is a plan of action that is intended to move a firm toward the achievement of its shorter-term goals and, ultimately, toward the achievement of its fundamental purposes (Harrison and St. John 2008). 
Strategy aims to achieve advantages for the organization by using available resources to meet the needs of the market and fulfill stakeholder expectations (Johnson and Scholes 2004). Business-level strategy defines an organization's approach to growth and competition in its chosen business segments (Harrison and St. John 2010). A firm's resources and capabilities determine its competitive advantage, which, in turn, gives rise to strategies for realizing that advantage (Grant 1991). The strategies describe how businesses compete in areas they have selected. The strategies may vary widely from business to business because they are shaped by competitive forces as well as the resources possessed by each of the units of the firm. If an organization is involved in only one area of business, then all of its business strategy decisions tend to be made by the same people. Such strategies are implemented through day-to-day decisions made at the operating level of a firm (Hrebiniak and Joyce 1984).

Business strategies are also shaped by forces external to the firm. The international literature on national business systems has shown how business organization and behavior varies from one country to another (Whitley 1992, 2008). Part of this variation can be observed in the type of strategies adopted by businesses in different places. Most of the work on business systems has emanated from industrialized countries and emerging economies in Asia and Eastern Europe, but there is a small, but growing literature on African business systems that points to similar differentiation in African economies (Pedersen and McCormick 1999, McCormick and Kimuyu 2007).

The collective day-to-day decisions made and actions taken by employees responsible for value activities create functional strategies. Functional strategy contains the details of how the functional areas such as marketing, operations, finance, and research \& development should work together to achieve the business level strategy (Harrison and St. John 2010). The competitive advantage and distinctive competences that are sought by the firms are often embedded in the skills, resources, and capabilities at the functional level. Functional strategies are the plans for matching those skills, resources, and capabilities with functional goals and activities.

\section{Strategy as a Framework for Analysis}

Functional strategies touch on the details of what will be done in each area of the business. In large businesses, such functional strategies are developed and implemented in functional departments. In smaller firms, the entrepreneur will be the main architect of strategy. In such small firms, neither the overall nor the functional 
strategies are necessarily written down. Whether written or not, the elements of a strategy can be identified and used as a framework for understanding the variations among firms.

\section{Methodology}

Research for this paper took the form of a scoping study that aimed at identifying the main features of strategy development and implementation among Nairobi's paratransit operators as seen by knowledgeable observers. It took, in other words, a "bird's-eye view" of the matatu industry. The scoping study was the first phase of a larger study of paratransit business strategies and regulatory compliance. The research team gathered primary data through 18 interviews of purposivelyselected key informants and feedback during a stakeholder workshop. Interviewees, who were chosen based on their institutional affiliation, were drawn from the Kenya Government (7), the private sector (9), and donor agencies (2) (see Table 1).

Table 1. Key Informants in Public Sector, Private Sector, and Donor Agencies

\begin{tabular}{|c|c|c|}
\hline Public Sector (KG) & Private Sector (KP) & Donor Agencies (KD) \\
\hline $\begin{array}{l}\text { - Ministry of Transport } \\
\text { - Ministry of Roads and Public } \\
\text { Works } \\
\text { - Ministry of Nairobi } \\
\text { Metropolitan Development } \\
\text { - Kenyan Urban Roads } \\
\text { Authority (KURA) } \\
\text { - Kenya Bureau of Standards } \\
\text { - Transport Licensing Board (TLB) } \\
\text { - Nairobi City Council }\end{array}$ & $\begin{array}{l}\text { - Citi Hoppa Ltd. } \\
\text { - Double M Services Express } \\
\text { Connections Ltd. } \\
\text { - Smart Bus Company } \\
\text { - MOA Compliant } \\
\text { - Star Bus Company } \\
\text { - KBS Management Ltd. } \\
\text { - Africa Merchant Assurance Co. Ltd. } \\
\text { - Equity Bank Kenya } \\
\text { - Family Bank }\end{array}$ & $\begin{array}{l}\text { - World Bank } \\
\text { - Japan } \\
\text { International } \\
\text { Cooperation } \\
\text { Agency (JICA) }\end{array}$ \\
\hline
\end{tabular}

Primary data collection used face-to-face interviews and observation. Interviewing of key informants ran from April to July 2010. Using pre-prepared interview guides, researchers asked all key informants to give their impressions of the basic operating strategies of the matatu business and to identify ways in which these strategies differ from one operator to another. Respondents were also asked additional questions, which were tailored to each informant's area of operation or expertise. A stakeholder's workshop was held in the month of July 2010 to discuss the initial findings of the scoping study and collect additional information. Researcher observations on matters such as driving behavior, the crowding of vehicles, and the nature of matatu driver and conductor interactions with passengers, other motorists, pedestrians, and police officers supplemented the interview material. 
Sources of secondary data included published literature, Web-based materials, government documents, and maps. The literature review covered books on urban transport, journal articles, newspaper articles, websites, reports, Government of Kenya documents, working papers, and discussion papers. Data analysis was qualitative and thematic. Themes were derived from the literature and the interview guides.

\section{Matatu Industry Organization and Business Strategies}

The research findings fall into two main categories: the general organization of the industry and/or industry segments and the business strategies of matatu firms.

\section{Strategy and Industry Organization}

To understand the general organization of the matatu industry in Nairobi, it is helpful first to look at organization as a concept and at its manifestations at the firm level. An organization in its simplest form is a person or group of people intentionally organized to accomplish an overall, common goal or set of goals. Business organizations can range in size from one person to tens of thousands and can be structured as one-person enterprises, partnerships, or multi-layered corporations (Nicolescu, 2009; Ricketts, 1994). The term "organization" is used in its basic dictionary sense of having an orderly structure or being systematized (Concise Oxford Dictionary 1990). The type and complexity of firm organization is sometimes taken for granted or considered as a simple function of business size, but size itself can be the outcome of decisions concerning the scope of the firm (Ricketts 1994). In other words, the type and level of organization are clearly related to the conscious decisions and strategies of the firm, and different strategies may be pointers to different levels of organization.

Analysis of the responses to questions about the strategies of matatu business yielded an overall picture of an industry made up of firms that vary considerably in their levels of organization. Using the main strategy types and the rough yardstick of "low," "moderate," and "high" levels of organization highlights some of the key differences found among firms in the sector (see Table 2).

The early research revealed three important points along what is expected to be a continuum of organization (see Figure 1). Based on our key informant interviews, we identified three main groupings. At the low end of the business organization scale was the typical matatu; next came the first group in the moderate organization range, the management companies. Finally, more organized but still in the 
moderate range, were Nairobi's larger transport business with multiple vehicles. No Nairobi operators were considered to be highly organized.

\section{Table 2. Strategy and Organization of Matatu Businesses}

\begin{tabular}{|c|c|c|c|}
\hline Strategy & Low Organization & Moderate Organization & High Organization \\
\hline $\begin{array}{l}\text { Business } \\
\text { ownership, } \\
\text { structure } \\
\text { and levels of } \\
\text { investment }\end{array}$ & $\begin{array}{l}\text { - Individual, owning one } \\
\text { or more vehicles }\end{array}$ & $\begin{array}{l}\text { - Group ownership } \\
\text { (family, partnerships, } \\
\text { cooperatives, limited } \\
\text { companies) }\end{array}$ & - Limited companies \\
\hline Financing & $\begin{array}{l}\text { - Self, family, and } \\
\text { friends }\end{array}$ & - Self, family and banks & - Investors and banks \\
\hline $\begin{array}{l}\text { Routes and } \\
\text { vehicle types }\end{array}$ & $\begin{array}{l}\text { - Operate in one route } \\
\text { allocated by TLB/ } \\
\text { control of routes by } \\
\text { gangs } \\
\text { - Considerable } \\
\text { deviation from routes } \\
\text { - Mainly } 14 \text {-seaters }\end{array}$ & $\begin{array}{l}\text { - Operate in one or } \\
\text { more than one routes; } \\
\text { routes controlled } \\
\text { by cooperatives } \\
\text { or management } \\
\text { companies; some } \\
\text { deviation from routes } \\
\text { - Mainly } 25-55 \text { seater } \\
\text { minibuses }\end{array}$ & $\begin{array}{l}\text { - Routes controlled } \\
\text { by legally mandated } \\
\text { transport } \\
\text { authorities; } \\
\text { complete adherence } \\
\text { to assigned routes. } \\
\text { - Mini and full-size } \\
\text { buses }\end{array}$ \\
\hline Pricing & $\begin{array}{l}\text { - Flat zoned, variation } \\
\text { with traffic and } \\
\text { weather }\end{array}$ & $\begin{array}{l}\text { - Flat zoned, monthly } \\
\text { coupons and smart } \\
\text { cards }\end{array}$ & $\begin{array}{l}\text { - Seasonal tickets } \\
\text { which are } \\
\text { transferable, no } \\
\text { deviations allowed }\end{array}$ \\
\hline $\begin{array}{l}\text { Operations } \\
\text { - repair and } \\
\text { maintenance, } \\
\text { recruitment }\end{array}$ & $\begin{array}{l}\text { - Individually } \\
\text { undertaken by each } \\
\text { operator }\end{array}$ & $\begin{array}{l}\text { - Done by management } \\
\text { companies }\end{array}$ & - Centralized \\
\hline $\begin{array}{l}\text { Regulatory } \\
\text { compliance }\end{array}$ & $\begin{array}{l}\text { - Low or non-existent } \\
\text { compliance }\end{array}$ & $\begin{array}{l}\text { - Complies with some, } \\
\text { but not all, regulations }\end{array}$ & - Full compliance \\
\hline $\begin{array}{l}\text { Promotion and } \\
\text { advertising }\end{array}$ & $\begin{array}{l}\text { - Individual promotion } \\
\text { through touting at } \\
\text { stages }\end{array}$ & $\begin{array}{l}\text { - Some advertising on } \\
\text { vehicles }\end{array}$ & $\begin{array}{l}\text { - Centralised } \\
\text { advertising strategy }\end{array}$ \\
\hline $\begin{array}{l}\text { Customer } \\
\text { relations }\end{array}$ & - Not emphasized & - Guidelines given & - Emphasized \\
\hline $\begin{array}{l}\text { Business } \\
\text { linkages and } \\
\text { networking }\end{array}$ & $\begin{array}{l}\text { Mainly personal ties } \\
\text { and linkages through } \\
\text { informal groups }\end{array}$ & $\begin{array}{l}\text { - Mix of formal and } \\
\text { informal linkages }\end{array}$ & $\begin{array}{l}\text { - Predominance of } \\
\text { formal linkages }\end{array}$ \\
\hline
\end{tabular}

Source: Authors' conceptualization from field data. 


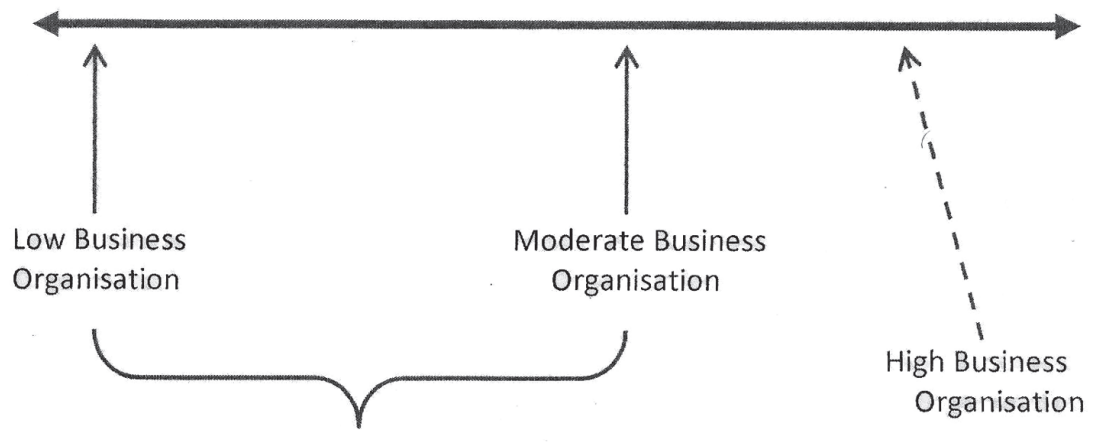

Nairobi firms fall here

Source: Authors' conceptualization

\section{Figure 1. Continuum of Public Transport Business Organization}

\section{Firm-level Organization}

The notion of a continuum of organization in the matatu industry that emerged in the previous discussion provides a backdrop for a more detailed understanding of the organization and behavior of individual firms in each of the three categories.

\section{Low Business Organization: The Typical Matatu}

The "typical" matatu is a 14-seater van owned by an individual who is involved in the transport business as a sole owner/driver or as side venture to employment or other types of business. The vans are bought second-hand in Kenya or directly from Japan and represent an investment of just over Kshs 1 million $\left(\$ 12,820\right.$ US). ${ }^{2}$ In the "typical" category also- mainly because they are very common on some routes-are the larger mini-buses that are usually bought new from Kenyan assemblers, mainly General Motors Kenya. The latest of these to enter the market has 37 seats and carries a price tag of Kshs 3.8 million ( $\$ 48,718$ US) (Daily Nation, 16 June 2010). Our observations suggest that older large buses are being recycled into use as matatus on some routes, while, in some cases, the mini-buses are converted Lorries. Installing an entertainment system can considerably increase the investment in any type of matatu.

The fare strategy is designed to maximize profits and minimize the owner's direct involvement in the management of the vehicle. The common use of a "target system," however, means that the vehicle owner receives a fixed daily amount while increases or decreases in revenues mostly affect the amount retained by the crew (KG). ${ }^{3}$ The crew is responsible to pay for fuel and other daily expenses except repairs 
and maintenance from the daily collections. The target system allows the crew to keep anything above the agreed amount, thus increasing their incentive to do whatever is necessary to maximize their revenues (KG). The fare itself is usually a flat-zoned fare, which is increased in peak periods and doubled or more when it rains or the vehicle is caught in heavy traffic jams. The owner's profit goal, however, is not always realized because the crew sometimes fails to meet the target.

Key informants emphasized that the typical matatu is poorly managed. Its daily operations are in the hands of the crew with little or no supervision from the owner. Owners lack management skills and the crew lacks basic training. There is little banking or record keeping (KG). Vehicles shun timetables in order to travel with a full load. Cutthroat competition results in vehicles over-speeding, picking and dropping passengers anywhere along the route, and deviating from prescribed routes to avoid obstacles or traffic jams (KG, KP, SW). Owners condone over-speeding, in some cases authorizing the removal of speed governors (KG). Profit rather than service is the main concern (KG). The typical matatu hires unqualified crew, over which the owner has little control. Respondents say that most are dropouts from secondary school (KG, SW).

Many vehicles are uninsured (KG). Those with insurance mostly have only thirdparty cover (KP). ${ }^{4}$ This leaves owners vulnerable to damage caused by accidents and, in some cases, penalties for failing to comply with regulations requiring at least third-party cover. The typical matatu's frequent accidents are blamed on the carelessness of the drivers (KG). Vehicles are constantly on the road, because owners are reluctant to rest them. One industry player observed that it is not possible to employ crew on contracts providing for time off because when a vehicle is off the road there is no income to pay the crew (SW). Maintenance costs for the vehicles are high, and a vehicle's useful life is fairly short.

Crew members display unruly behaviour and a "don't-care" attitude towards both passengers and the vehicle itself (KG, KP). Customer relations are poor. Drivers and conductors rarely see passengers as "customers." Although conductors show and/or call out the number and destination to attract passengers into the matatu, once passengers board the vehicle they may be harassed or treated badly. Some 14-seaters have music systems, but the choice of music and control of its volume is at the discretion of the crew. Passengers' occasional complaints are usually disregarded. Many mini-buses have more elaborate entertainment systems in an effort to attract the youth market on some routes. 
The typical matatu operates on its own, with little interaction between its owner and the owners of similar vehicles. Only a small proportion of owners belong to an association, and 14-seater matatus are not included in existing franchise arrangements. This is changing as a result of the Transport Licensing Board's 2010 directive requiring public service vehicle (PSV) owners to join organized groups such as savings and credit co-operatives (SACCO) or companies in order to be registered (Daily Nation, 23 December 2010). Since the beginning of 2011, stand-alone matatus are not eligible for registration.

\section{Moderate Business Organization: Matatu Management Companies}

Three companies presently operating in Nairobi as management companies fit into the moderate business organization category. All three of these manage buses on behalf of individual investors, providing a range of services.

The basic concept underlying the management companies is franchising. A franchise can be loosely defined as an authorization to sell a company's goods or services in a particular place. The person or entity who owns the business, its trademark, and the system is the franchisor. The entity authorized to sell is the franchisee. In this case, the management company (franchisor) generally holds a trademark and a set of operating procedures, services, and/or standards that the individual matatu owner (franchisee) buys the right to use.

Two of the franchise companies interviewed operate solely as managers of vehicles for individual owners. The third has both franchised vehicles and owned vehicles. The companies differ in their requirements for obtaining a franchise, the services offered, funds management procedures, vehicle specifications, and operating rules. In all cases, the public can easily recognize the franchised buses by their color and design. One of the management companies originally required that its franchisees have at least five vehicles, but found difficulty in enforcing this rule (KP). Other industry stakeholders refer to them as examples of what a more organized transport system might look like.

\section{Moderate Business Organizations: Bus Companies ${ }^{5}$}

A bus company can usually exert more control over its operations than a management company. Bus companies represent a second form of moderate business organization. Our research identified two companies with fleets of buses. A "fleet" can be defined as group of buses operating together under the same ownership. These are, therefore, companies that own and operate their own vehicles, includ- 
ing hiring and training their own staff. Both are private companies offering public transport services.

Defining a fleet as a group gives considerable latitude for variations in size. One Nairobi bus company has only 15 vehicles but aspires to have 300 in the future; another already has 200 . The next stage of the research may yield data that will enable us to estimate the size of fleet necessary for a viable company.

Formulating strategy in a unified company is basically the task of the owners, who can put in place appropriate measures to implement their ideas. Our bus company interviews focused on the respondent views of matatu operations and, therefore, did not yield full information on the companies' own strategies. Further interviews to fill the gaps on company strategy will be conducted in the next phase.

Although the bus companies are better organized than most public transport players in Nairobi, they cannot be considered to be highly organized for two reasons. First, most lack the ticketing and fleet management systems that would be necessary for the highest degree of organization (SW). Second, although company vehicles follow regulations to a greater extent than matatus in either the low or moderate organization groups, researchers have observed enough violations to support their judgment that these firms have not yet achieved the "full compliance" expected of highly-organized transport providers.

\section{Summary and Conclusions}

\section{Summary}

Interviews of informed observers - the "bird's-eye view" - provided new information about matatu industry organization and its individual business enterprises. The first and perhaps most important finding is that the industry shows considerable variation in business structure, modes of operation, levels of organization, and attitudes towards regulation. To highlight this finding, we proposed a continuum of organization, with the "typical" individually-owned matatu at one end and the multi-vehicle bus company near the other end. We noted that no Nairobi bus company could be called "highly organized" by international standards.

The second finding has to do with the strategies of individual businesses. Eight elements of a business strategy appear to apply to matatu businesses: 1) business ownership and investment; 2) financing; 3 ) routes and vehicle types; 4) pricing; 5) operations; 6) promotion and advertising; 7) customer relations; and 8) business linkages and networking. The findings suggest that these elements are present in 
varying degrees and combinations. In theory, at least, each matatu business can develop its own unique strategy by combining the elements in different ways. The extent to which this actually happens and which strategies seem to work best in the Nairobi environment require further research.

\section{Conclusions}

The study has yielded three main conclusions. First, this "bird's-eye view" demonstrates that keen observers can identify various elements of business strategy in the matatu sector. It is not possible, however, at this level to know all of the variations and commonalities of these strategies, nor to understand the motivation behind their adoption by particular firms. More importantly, it is not possible, without detailed case studies, to understand the links between business strategy and firm choices to comply or not comply with traffic and operational regulations.

Second, it is clear that Nairobi's public transport system has grown, adapted, and reorganized itself many times in the past few decades. It appears that this evolutionary process is continuing with the emergence of franchising, networking, ownership of multiple vehicles, and, most recently, the promotion of transport savings and credit cooperative organisations (SACCOs). It is possible that further development of varied organizational forms could hold the key to a more userfriendly public transport system for Nairobi.

Finally, the findings have implications for the formation and application of policies and regulations. In what appears to be a quite varied landscape of matatu businesses, policymakers and regulators need to listen keenly to the full range of matatu voices. This is difficult in the present, somewhat disorganized industry structure. The directive calling for improved organization through SACCOs and transport companies has the potential to improve communication channels, but it also runs the risk of putting into place organizations that lack credibility across different matatu types. Nevertheless, the development of varied organizational forms is a hopeful sign that could hold the key to a more user-friendly public transport system in Nairobi.

\section{Endnotes}

${ }^{1}$ We take the classic definition of a firm as "the system of relationships which comes into existence when the direction of resources is dependent upon an entrepreneur" (Coase 1937). 
${ }^{2}$ At the time of the research, the exchange rate was approximately Kshs 78 to the US dollar.

${ }^{3} \mathrm{~K}=$ data from key informant interviews; SW = data collected from the stakeholder's workshop; G, P, D = interview data from government, private sector, and donors.

${ }^{4}$ Third-party cover is liability insurance purchased by an insured (the first party) from an insurer (the second party) for protection against the claims of another (the third) party. The first party is responsible for its own damages or losses whether caused by itself or the third party. A matatu carrying third-party cover will be insured against damages to other persons and their property in accidents it causes. See http://www.businessdictionary.com/definition/third-party-insurance. html\#ixzz2BbpfOh62.

${ }^{5}$ For purposes of this research, a "bus company" is a company that 1) owns some or all of the vehicles it operates and 2) has or aspires to have a large fleet of vehicles operating on multiple intra-city routes. The bus companies included in this research generally operate mini- and/or full-size buses. The term is preferred to its logical alternative - a matatu company-because it is recognized in the industry in Nairobi as a specific group of operators.

\section{Acknowledgments}

The authors gratefully acknowledge financial support from the Volvo Research and Educational Foundations (VREF), as well as comments and suggestions received from participants in the Southern Africa Transport Conference 2011 and research workshops organized by the African Centre of Excellence for Studies in Public and Non-motorised Transport (ACET) based at the School of Engineering, University of Cape Town, and anonymous reviewers. Any remaining errors or omissions remain our responsibility.

\section{References}

Aligula, E., Z. Abiero-Garly, J. Mutua, F. Owegi, C. Osengo and R. Olela, 2005. Urban public transport patterns in Kenya: A case study of Nairobi City. Special Report No.7. Nairobi: KIPPRA. 
Boudreaux, K. 2006. Taxing Alternatives: Poverty Alleviation and the South African Taxi/Minibus Industry. Arlington: Mercatus Centre.

Cervero, R., and A. Golub. 2007. Informal transport: A global perspective. Transport Policy 14: 445-447.

Cervero, R. 2000. Informal transport in the developing world. Nairobi: United Nations Commission on Human Settlement.

Cervero, R. 1997. Paratransit in America. West Port, CT: Praeger.

Chitere, P. 2009. Matatu paratransit industry in Kenya: A study of its associations and companies and their potential to contribute to road safety. Journal of Intra-African Studies 2:121-142.

Chitere, P. 2006. Public service vehicles in Kenya: Their characteristics and compliance with traffic regulations and prospects for the future. DP No. 081. Nairobi: IPAR.

Chitere, P., and T. Kibua, 2004. Efforts to improve road safety in Kenya: Achievements and limitations of reforms in the matatu industry. Nairobi: IPAR.

Coase, R. 1937. The nature of the firm. Economica 4: 386-405.

Concise Oxford Dictionary, 8th Edition. 1990. Oxford: Clarendon Press.

Daily Nation. 2010. Public notice: Transport Licensing Board. 23 December.

Daily Nation. 2010. Kenya: New deal to make buying matatus easy. 16 June.

Daily Nation. 1999. "Matatu madness" must be stopped. 9 July.

East African Standard (Nairobi). 1998. Victims of "matatu madness," 15 December.

Finn, B., Kumarage, A., and Gyamera, S. 2011. Organizational structure, ownership and dynamics on control in the informal local road passenger transport sector. Paper presented at Thredbo 12 Conference Series, Durban, South Africa.

Finn, B., and C. Mulley. 2011. Urban bus services in developing countries and countries in transition: A framework for regulatory and institutional developments. Journal of Public Transportation 14(4): 89-107.

Golub, A. 2005. Regulating small-scale transit operators. Presentation to Diálogo Regional sobre las Políticas de Transporte Urbano Quito, Ecuador, November.

Grant, R. M. 1991. The resource based theory of competitive advantage: Implications for strategy formulation, California Management Review 33(3): 114-135. 
Harrison, J. S., and C. H. St. John. 2008. Foundations in Strategic Management, 5th Edition. Mason, $\mathrm{OH}$ : South-Western Cengage Learning.

Hrebinak L. G., and W. F. Joyce, 1984. Implementing strategy. New York: Macmillan. Illes, R. 2005. Public Transport in Developing Countries. Amsterdam: Elsevier.

Johnson, G., and Scholes J. 2004. Exploring Corporate Strategy, 6th Edition. Hemel Hempstead: Prentice Hall.

Kelly, S., and A. Kouzmin, 2009. Reframing strategic thinking: Emergence beyond the box. Journal of Management Development 3: 1-3.

Khayesi, M. 2002. Struggle for socio-economic niche and control in the matatu industry in Kenya. DPMN Bulletin IX (2): 1-12.

Kumar, A., and F. Barrett. 2008. Stuck in traffic: Urban transport in Africa. Africa Infrastructure Country Diagnostic 44980. Washington: The World Bank.

Lee, E. 1990. Formalizing informal transport: Paratransit in Hong Kong. In Margaret J Heraty (ed.), Developing World Transport. London: Grosvenor Press International.

McCormick, D., and P. Kimuyu. 2007. Business systems theory: An African perspective. In D. McCormick, P. O. Alila and M. Omosa (eds). Business in Kenya: Institutions and Interactions. Nairobi: University of Nairobi Press.

McCormick, D., W. V. Mitullah, P. Chitere, R. Orero, and M. Ommeh. 2011. Institutions and business strategies of matatu operators in Nairobi: A scoping study. ACET Working Paper No. 14-2. African Centre of Excellence for Studies of Public and Non-Motorised Transport. Cape Town: University of Cape Town.

Mũnoz, J., and A. Gschwender. 2008. Transantiago: A tale of two cities. Research in Transport Economics 22: 45-53.

Nicolescu, O. 2009. Main features of SMEs organization systems. Review of International Comparative Management 10 (3): 405-413

Örn, H. 2005. Chapter 5. Urban public transport in an international perspective. In Jönson, G., and E. Tengström (eds.) Urban transport development: A complex issue, pp. 45-64. Berlin: Springer.

Pedersen, P. O. and D. McCormick, 1999. African business systems in a globalising world. Journal of Modern African Studies 37(1): 109-135. 
Ricketts, Martin. 1994. The Economics of Business Enterprise: An Introduction to Economic Organization and the Theory of the Firm, 2nd Edition. London: Harvester Wheatsheaf.

Schalekamp, H., D. Mfinanga, P. Wilkinson, and R. Behrens. 2008. An international review of paratransit regulation and integration: Lessons for public transport rationalisation and improvement in African cities. Cape Town: ACET. http:// www.fut.se/download/.

Sclar, E., J. Touber, and C. Alexander. 2007. Rethinking privatization: The case of urban transportation in Nairobi, Kenya. Association of Collegiate Schools of Planning Annual Meeting, 20 October, Milwaukee.

Sohail, M., D. A. C. Maunder, and D. W. J. Miles. 2005. Managing public transport in developing countries: Stakeholder perspectives in Dar es Salaam and Faisalabad. International Journal of Transport Management 2: 149-160.

Vuchic, V. R. n.d. Urban public transportation systems. www.eng.wayne.edu/ user_files/155/urban_pub_tr_sys_Vuchic.sys. Accessed 12 June, 2012.

Whitley R. 1992. Business Systems in East Asia: Firms, Markets, and Societies. London: Sage.

Whitley, R. 2008. Business Systems and Organizational Capabilities: The Institutional Structuring of Competitive Competencies. Oxford: Oxford University Press.

Wilkinson, P. 2008. Formalising paratransit operations in African cities: Constructing a research agenda. Proceedings of the 27th Southern African Transport Conference: $480-490$.

Wilkinson, P., A. Golub, R. Behrens, P. S. Ferro, and H. Schalekamp. 2011. Transformation of urban public transport systems in the Global South. In H. S. Geyer (ed.), International Handbook of Urban Policy, Vol. 3, Issues in the Developing World. Cheltenham: Edward Elgar Publishing Ltd.

\section{About the Authors}

DOROTHY MCCORMICK (dmccormick@uonbi.ac.ke) is a Research Professor at the Institute for Development Studies, University of Nairobi, where she has been a member of staff since 1988. From 2001 until 2007, she was the Institute's Director. She has a long history of research and teaching in the area of industrialisation and enterprise development in Africa. Her work has dealt with the institutions affect- 
ing enterprise development, enterprise clusters, and value chains and has spanned various sectors including, most recently, urban public transport.

Winnie MitullaH (wmitullah@uonbi.ac.ke) is Associate Research Professor at the Institute for Development Studies, University of Nairobi. She specializes in urban development and has a long history of research and engagement with informal sector actors and institutions including the paratransit sector in Nairobi.

Preston Chitere (pchitere@uonbi.ac.ke) is a rural sociologist with a leaning toward participatory rural development. He holds a B.A (Hon.), an M.Sc. in Agricultural Extension, and a Ph.D. in Rural Sociology (1980) from the University of Nairobi. He undertook post-doctoral studies and research at lowa State University in 1986-87. He is currently the Dean, Faculty of Arts and an Associate Professor in the Department of Sociology and Social Work, University of Nairobi. He previously served as policy researcher at the Institute of Policy Analysis and Research (IPAR), Nairobi and as a social scientist at the International Centre of Insect Physiology and Ecology (ICIPE), Nairobi.

RISPER ORERo (risper.orero@kemu.ac.ke) is Senior Lecturer in Business Administration at the Kenya Methodist University, Nairobi campus. She holds a Ph.D. from the University of Nairobi, where she specialized in entrepreneurship.

MARILYN OMMEH (saramital@yahoo.com) is a project assistant at the Institute for Development Studies, University of Nairobi, where she has been a member of the staff since 2009. She holds a Master of Arts degree in Development Studies from the Institute for Development Studies. Her research interests are development policy analysis and urban development issues such as public transport and livelihoods. 